Volume 5, Issue S2 (2020), pp. 100-104 Journal of School Administration Research and Development ISSN: 2470-8496 Print/ ISSN: 2470-850X Online ojed.org/jsard

\title{
Pedagogical Transformation Models in Schools in Nepal during the Global Pandemic
}

\author{
Yadu P. Gyawali \\ Mid-Western University, Nepal
}

\begin{abstract}
This essay reviews the emergency teaching-learning pedagogy in K-12 schools of Nepal during the COVID-19 global pandemic. It discusses three models (unidirectional, e-participatory, and mobile teaching) as alternative pedagogies of Nepalese educational institutions to continue teaching-learning for different disciplines such as language, arts, and social studies. Moreover, the essay discusses the appropriateness of each model for teaching-learning in urban, semi-urban, and rural settings in Nepal.
\end{abstract}

Keywords: distance learning, pandemic, participatory

The global spread of the COVID-19 pandemic has badly affected the education sector. Huber and Helm (2020) state that most of the world's countries have experienced such a crisis, and many schools have been closed since mid-March of 2020. But educators and stakeholders still do not have a clear map of dealing with the current teaching-learning situation. Therefore, this is the high time to research relevant information and knowledge to find the quickest way out of this context by developing a better understanding and contextual insights of teaching in the new normal.

Rauniyar (2020) reports in the context of Nepal that the COVID-19 pandemic has affected all spheres of human life, including education. Consequently, Nepali schools and colleges have been closed for months when the government declared locked down entirely on March 24, 2020. In this situation, educational stakeholders and policymakers were in a dilemma to either close the 
institutions to minimize the spread of coronavirus and keep students safe or to continue in-person classes. They further reported that many schools and colleges have been teaching in distance and online mode based on the available technologies for which different digital conferencing tools such as Zoom and Google Meet support the online delivery of education and information to engage with students.

The students are compelled to stay at home as academic institutions have been closed in Nepal due to the nationwide lockdown to prevent the mass-spread of the virus, and it affects their education. Mahmut (2020) reported that the lockdown affected billions of students and millions of educators around the world in their teaching-learning. Moreover, the author discussed the role of digital learning in strengthening opportunities and distance learning support as an alternative educational strategy for teaching and learning for the current situation. Similarly, Nepal Education Cluster (2020) has suggested online and distance education and digital tools for teaching-learning as the alternative strategy.

There are many alternative tools to connect to online learning communities, such as Google Classroom, MOODLE, MOOCs, Coursera, Canvas, Blackboard, and WizIQ (Zhou et al., 2020). These tools can be the standard platforms for sharing resources, designing assignments, updating attendance, providing individual feedback, and grading students' assignments. Owusu et al. (2015) suggested that the teacher's technological pedagogical content knowledge (TPACK) is required to effectively implement online teaching-learning strategies. Similarly, Setiawan and Phillipson (2020) reported a correlation between teachers' technological, pedagogical, and content knowledge. They suggested using social networks such as Facebook, YouTube, Twitter, email, and blogs in the classroom to introduce the new learning modalities.

In this context, Nepal has introduced three different pedagogical strategies for teaching first and second languages (particularly English) and other disciplines such as mathematics, social studies, and science in this global pandemic. The models are based on digital infrastructure and frameworks, distance-based pedagogy, resource availability, learners' access, financial aspects, and societal frameworks in Nepal.

\section{Model 1: Unidirectional Model (Distance Mode of Learning)}

The unidirectional model has been widely practiced in Nepal as the distancemode strategy to deliver lessons using different communication means such as radio, television, and telephone. In this model, teachers are planning, developing, and teaching different subjects by collaborating with different community and national radio stations and television channels. The model seems practical for geographically scattered learners, and it is widely practiced by teachers targeting 
urban and rural areas for teaching-learning activities through radio, television, and telephone.

The Nepal government has collaborated with many television channels and FM radios for the implementation of this model during the global pandemic. For effective implementation of this model, local educational authorities and school leaders collaborated with television and FM stations as per their convenience to conduct classes. This model needs further promotion, as it has a wider scope and broader coverage for many students' benefits.

\section{Model 2: E-Participatory Model}

The e-participatory model is an online-based, social media-centered, and virtual way of teaching. It engages students into virtual platforms such as Zoom, Google-meet, Facebook live, Google Classroom, and Edmodo. These modes of instruction have become more advantageous in addressing the present alternative demand. According to Gulati (2008), teachers and learners can create open, independent, and accessible educational insights with ICT framework dynamic features in the classroom. The world's educational system has been adopting and experiencing various online learning management systems, such as incorporating ICT, social media, and web tools in teaching-learning. Different kinds of online tools and learning management systems have been used extensively in the classrooms to plan and share lesson contents, record attendance, provide assignments, and give feedback.

The e-participatory model is highly synchronized and interactive, as it allows learners to participate in teaching-learning activities, and they may feel the learning context of their real classroom. This model is more effective than the unidirectional model, as the e-participatory model seems natural, practical, interactive, and conditional.

\section{Model 3: Mobile Teaching}

This is a largely practiced alternative strategy of providing education at the time of the COVID-19 crisis in Nepal. In this model, teachers teach students by collecting them in public places, school buildings, or even open outdoor spaces. Many teachers also visit different villages and residential areas within school boundaries to collect students for teaching. These teachers are very active, visiting door-to-door for teaching and learning. Moreover, this model assists community engagement initiatives for the professional development of teachers.

Mobile teaching seems widely practiced in Nepal's rural schools where there is no internet access or other information and communications technologies to run virtual teaching-learning through online platforms. As a result, e- 
participatory model is not practical for them. Additionally, these students do not listen to the radio or watch television programs. So, they do not have the access to the unidirectional model. In this scenario, the mobile model gives the rural students access to a teacher to continue their education. And though the teachers and students have face-to-face interactions, the rural setting allows for social distancing to protect from COVID-19 spread.

\section{CONCLUSIONS/ IMPLICATIONS}

The COVID-19 global pandemic can bring about a new skill and knowledge transformation in education, intervening alternative pedagogies for the appropriate solutions to settle the halt and closure of academic institutions. This essay focuses on the use of three different models to make such a transformative pedagogical shift. The unidirectional model focuses on the synchronous use of broadcasting media such as radio, television, and telephones for teaching. Similarly, the e-participatory model emphasizes both asynchronous and synchronous coverage associated with computer-assisted and internet-based teaching-learning strategies. The mobile teaching model adds a new flavor of community-based teaching-learning practices where teachers form the community group. Teaching-learning activities occur in face-to-face mode, maintaining social distancing, as per coronavirus safety protocols.

Moreover, these models can bring an epistemological shift in the practice of teaching-learning and assessment during the global pandemic in Nepal. Similarly, the models discussed in this essay reveal the alternative use of the strategies based on resource availability. For example, the e-participatory model requires the use of internet resources for pedagogical practices, which is useful to the urban and semi-urban areas. However, the mobile teaching model seems appropriate in Nepal's rural areas, where there are fewer students and a lack of internet resources. Furthermore, teacher and administrator roles and responsibilities to design and practice the different strategies and seek alternative pedagogies for addressing each situation is necessary for the appropriate use of the strategies.

However, Nepal has been gradually expanding its technological capacity, as ICT development has enabled teachers to have internet access. Now it is time for the teacher to achieve ICT skills and to run teaching-learning using electronic devices. Therefore, policymakers, administrators, and teachers need research to develop concrete plans for teaching-learning that will be practical for the postCOVID-19 situation. 


\section{REFERENCES}

Gulati, S. (2008). Technology-enhanced learning in developing nations: A review. The International Review of Research in Open and Distributed Learning, 9(1).

Huber, S. G., \& Helm, C. (2020). COVID-19 and schooling: evaluation, assessment and accountability in times of crises - reacting quickly to explore key issues for policy, practice and research with the school barometer. Educational Assessment, Evaluation and Accountability, 1-34.

Mahmut, Ö. (2020). Educational policy actions by the Ministry of National Education in the times of COVID-19 pandemic in Turkey. Kastamonu Eğitim Dergisi, 28(3), 1124-1129.

Nepal Education Cluster. (2020). COVID-19 Education Cluster Contingency Plan, 2020. https://doe.gov.np/assets/uploads/files/04caa85f3247842d8175a25d5bcccdbc.pd f

Owusu, K. A., Conner, L., \& Astall, C. (2015). Assessing New Zealand high school science teachers' technological pedagogical content knowledge. Journal of Computers in Mathematics and Science Teaching, 34(3), 345-373.

Rauniyar, M. (2020, June 2, 2020). Education under Covid-19. The Kathmandu Post. https://kathmandupost.com/columns/2020/06/02/education-under-covid-19

Setiawan, H., \& Phillipson, S. (2020). The Correlation between Social Media Usage in Academic Context and Self-Efficacy towards TPACK of Prospective Science Teachers in Indonesia. Journal of Science Learning, 3(2), 106-116.

Zhou, L., Li, F., Wu, S., \& Zhou, M. (2020). "School's out, but Class's on", the Largest Online Education in the World Today: Taking China's Practical Exploration during the COVID-19 Epidemic Prevention and Control as an Example [Reports -Descriptive]. Best Evidence of Chinese Education, 4(2), 501-519.

Yadu P. Gyawali is an assistant professor at Mid-Western University in Nepal. His email address is yadu@mwu.edu.np 